\title{
On two Bathypontiidae (Calanoida, Copepoda, Crustacea) collected off South America
}

\author{
TAGEA K. S. BJÖRNBERG \\ (Departamento de Zoologia - Univ. de São Paulo)
}

\section{A B S T R A C T}

Bathypontia kanaevae n. sp. is described from the South Atlantic and $B$. elongata Sars, 1905 from the South Pacific is commented upon.

\section{R E S U M O}

Duas Bathypontiidae (Calanoida, Copepoda, Crustacea) coletadas ao largo da América do Sul: Bathypontia kanaevae sp. n. é descrita do Atlântico Sul, com observações sobre $B$. elongata Sars, 1905 do Pacífico Sul.

\section{N T R O D U C T I O N}

The genus Bathypontia G.O. Sars, 1905, of the family Bathypontiidae Brodsky, 1950, contains several species: B. elongata Sars, 1905, B. major Wolfenden, 1906 (in Wolfenden, 1911), B. minor Wolfenden, 1906 (in Wolfenden, 1911), B. spinifera A. Scott, 1909, B. elegans Sars, 1920, B. longiseta, Brodsky 1950, B. similis Tanaka, 1965, and, B. sarsi Grice and Hülsemann, 1967.

In 1965 Vervoort stressed the necessity of reviewing critically the various species of Bathypontia. This was partially done by Grice \& Hülsemann in the same year. These authors created the new name $B$. sarsi for the Bathypontia minor Sars as this name was a junior homonym of B. minor (Wolfenden, 1906), and considered B. major (Wolfenden, 1906) as a senior synonym for Bathypontia elegans Sars, 1920. In a later paper Grice \& Hülsemann (1967) redrew the male fifth leg of a species identified as $B$. elongata and described the male of a new species, $B$. regalis. Wheeler (1970) redrew a copepod identified as $B$. sarsi, but probably a $B$. similis Tanaka. Both Wilson (1950) and Owre and Foyo (1967) figure $B$. sarsi Grice \& Hülsemann (= B. minor Sars). 
During the XIIth cruise of the Oc/S. "M. Lomonosov" to the South Atlantic and during the USNS "Eltanin" 3rd cruise to the Antarctic, 2 different species of Bathypontia were found. They did not correspond exactly to any of the described species, but resembled $B$. elongata and B. elegans.

The largest sized Bathypontia known is elongata. The Eltanin specimen corresponds in several details to $B$. elongata, in the gnathal lobe and in the rostrum.

Bathypontia major Wolfenden, 1906 (in Wolfenden, 1911) differs considerably in the fifth leg, in the length of the leg segments, from Bathypontia elegans Sars, 1920 though agreeing in other characteristics. Therefore the two species should be considered good till specimens with intermediate-shaped fifth legs are found.

\section{Bathypontia kanaevae n. sp. (Figs. 1-9, 12-17)}

Occurrence: at $14^{\circ} 00^{\prime} 4 \mathrm{~S}-35^{\circ} 01^{\prime} 6 \mathrm{~W}$, during the XIIth cruise of the "M. Lomonosov" to the South Atlantic, at a depth between 1000 and $300 \mathrm{~m}$, caught between $03: 05$ and $05: 20$ o'clock, in waters with 12,96 to $3,79^{\circ} \mathrm{C}$ temperature and 35,18 to $34.40 \%$ salinity, on November, 27, 1962.

Holotype: a female $7050 \mathrm{~mm}$ long, deposited at the Museu de Zoologia, Univ. of S. Paulo, Brazil, n. 3940.

Diagnosis: Prosome-mesosome with 6 free-segments, $5.650 \mathrm{~mm}$ long; and urosome, 4-segmented, $2.000 \mathrm{~mm}$ long. Last mesosome segment symmetrical but terminating in an almost square lappet, with posterior dorsal points, partly covering the first urosome segment. A strong laterodorsal indentation marks where the square-shaped lappet originates from the last segment. Rostrum duck-bill shaped with a little pointed protuberance to the left of its anterior margin. The labrum has a characteristic distribution of setules. Antennule $6 \mathrm{~mm}$ long, reaching beyond the genital segment, 24-jointed. The relative lengths of the joints are as follows: $20-25-33-20-20-12-16-25-20-30-25-25$ $-16-46-41-41-35-41-61-66-81-83-83-$ $77=1000$.

Basipod of antenna with 2 setae; exopod with 5 setae; endopod with 1 seta on first joint and $8+6$ setae on the distal joint.

Mandible blade with 2 one-pointed teeth, plus 2 bifurcated teeth, 10 spines, one plumose seta and setules which give a hairy aspect to the margin of the blade.

Figs. 1-11 - 1. Bathypontia kanaevae n. sp. - Second antenna. Scale = $1 \mathrm{~mm}$. 2. B. kanaevae n. sp. - Maxilliped. Scale $=0.20 \mathrm{~mm}$. - 3. Rostrum of B. kanaevae n. sp. - Scale $=0.10 \mathrm{~mm}$. - 4. Rostrum and mouth region of $B$. kanaevae in profile. Scale $=1 \mathrm{~mm}$. -5 . Semi-schematic view of the female B. kanaevae. Scale $=1 \mathrm{~mm}$. - 6. Maxillule of $B$. kanaevae. Scale $=0.20 \mathrm{~mm}$. -7 Lateral view of last mesosome and first urosome segments of $B$. kanaevae. Scale $=0.20 \mathrm{~mm}$. -8 . Mandibular palp of $B$. kanaevae. Scale $=0.20 \mathrm{~mm}$. -9 . First swimming limb of $B$. kanaevae. Scale $=$ $0.20 \mathrm{~mm}$. - 10. Profile of rostrum of the Eltanin B. elongata Sars. Scale $=0.10 \mathrm{~mm}$.

11. Rostrum of the Eltanin B. elongata Sars in front view. Scale $=0.10 \mathrm{~mm}$. 


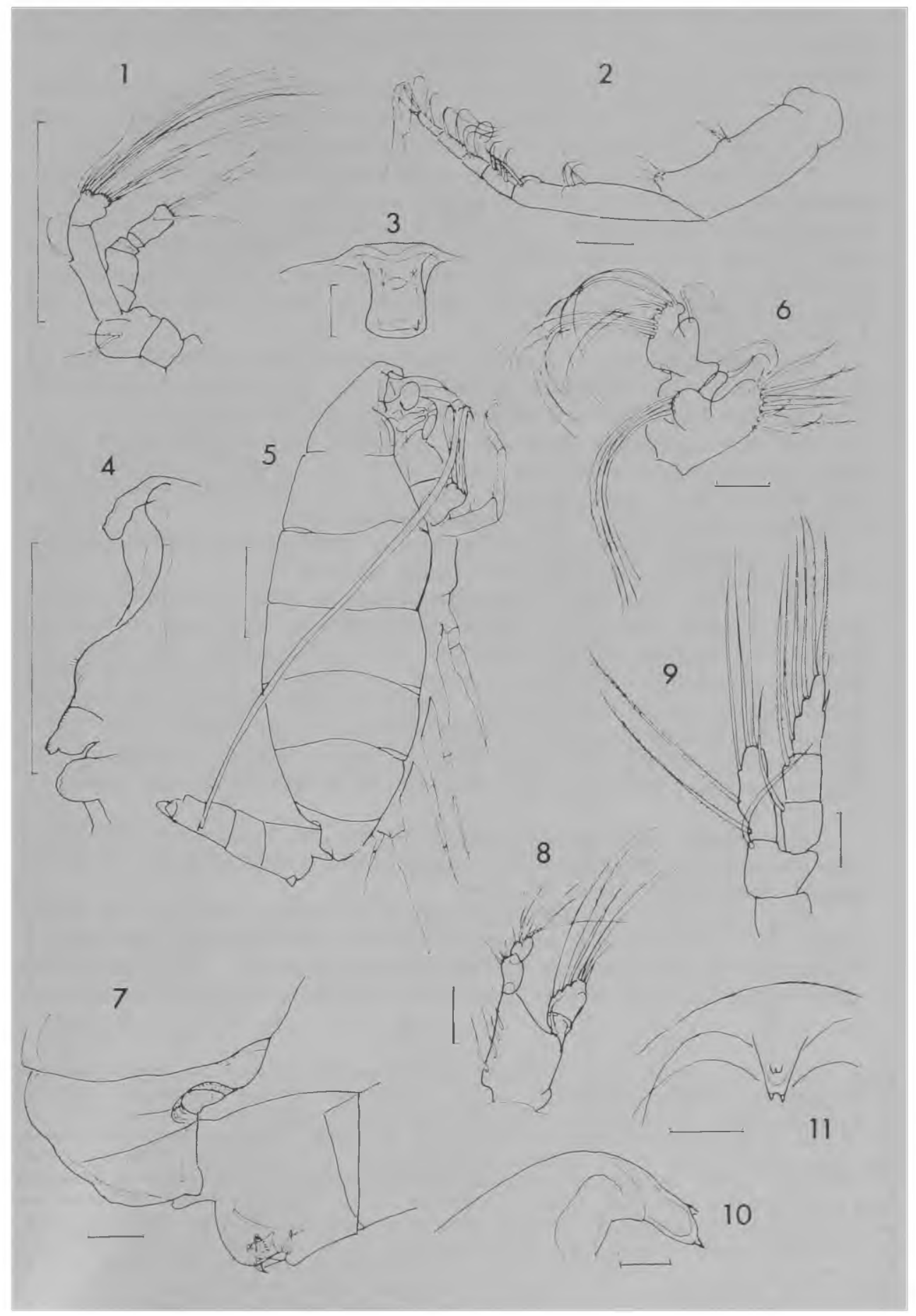


The mandible palp has 4 setae on the basipod, 3 setae on the first endopod joint, 8 setae on the second endopod joint, 1 seta on the first exopod joint and 6 setae on the following.

The maxillule has 4 long setae on the exite, 10 long hooks on the first endite, 1 seta on the second and 1 seta on the third endite; 1 seta on the basipod; no endopod; 10 setae on the exopod.

The maxilla has 6 strong, long setae with a characteristic flange-like distribution of setules at the end and 2 small setae of the same type on the two most distal joints. The fourth joint has a hairy protuberance with 2 strong setose setae and 1 small seta with a flange-like double row of setules on the distal third. The third joint has 2 plumose spines on a hairy protuberance. The second joint has 2 hairy protuberances with 1 plumose spine each.

The maxilliped has 1,2 and 3 short setae on the coxopod, a tuft of 3 and another of 2 short setae on the basipod. The endopod joints have from the first to the last respectively $4,4,2,3+2$ thin spiralled setae.

The first swimming limb has a 3-jointed exopod with 1-1-4 inner setae, one setuled terminal seta and 2 outer thin spines on the last joint. The basipod has 1 long plumose seta and the one-jointed endopod has 4 plumose inner setae +1 terminal plumose seta.

The second, third and fourth swimming limbs have 3-jointed exopods and endopods and a plumose seta on the basipod.

The second, third and fourth swimming limbs have a 3-jointed exopod with $1: 1: 5$ inner setae, $1: 1: 3$ outer spines and one long serrated terminal spine. The endopod is also 3-jointed with 1:2:7 setae. The setae are plumose especially of the first endopod joint and of the coxopod, which is also setose on the inner border. The fifth limb has the characteristic aspect of this appendage in the Bathypontia: 3 joints with a long and a short terminal spine. The long spine is longer than the remaining fifth limb. The short spine is about one third the length of the last joint.

Discussion: The specimen caught by the "M. Lomonosov" off Brazil also resembles $B$. elongata and $B$. major in the mandible blade. It is the largest Bathypontia found till now.

The rostrum is slightly asymmetrical in frontal view but not bifurcated. The fifth thoracic segment is almost square-shaped and pointed. The border of the segment is broadly indented dorsally. The labrum does not correspond to the labrum figured for B. elegans Sars but the rostrum,

Figs. $12-23-12$. Front view of the labrum and partial view of the labial armature of $B$. kanaevae. Scale $=0.20 \mathrm{~mm}$. -13 . Free border of the mandibular blade of B. kanaevae. Scale $=0.10 \mathrm{~mm}$. -14 . Antennule of $B$. kanaevae. Scale $=1 \mathrm{~mm}$. 15. Maxila of $B$. kanaevae. Scale $=0.20 \mathrm{~mm}$. -16 . Fifth swimming limb of $B$. kanaevae. Scale $=0.10 \mathrm{~mm}$. - 17 Third swimming limb of $B$. kanaevae. Scale $=1 \mathrm{~mm}$. 18. Posterior border of mesosome and first urosome segment of the Eltanin B. elongata Sars seen from the right side. Scale $=0.20 \mathrm{~mm}$. - 19. Posterior border of mesosome and urosome of the Eltanin B. elongata Sars seen from the left side. Scale $=1 \mathrm{~mm}$. 20. Labrum, mandible blade and labial armature of $B$. elongata from the left side. Scale $=0.10 \mathrm{~mm}$. -21 . Mandible blade of the Eltanin B. elongata Sars. Scale $=0.20$ $\mathrm{mm}$. - 22. Maxilliped of the Eltanin B. elongata. Scale $=0.20 \mathrm{~mm}$. -23 . Fifth swimming limb of the Eltanin B. elongata. Scale $=0.10 \mathrm{~mm}$. 


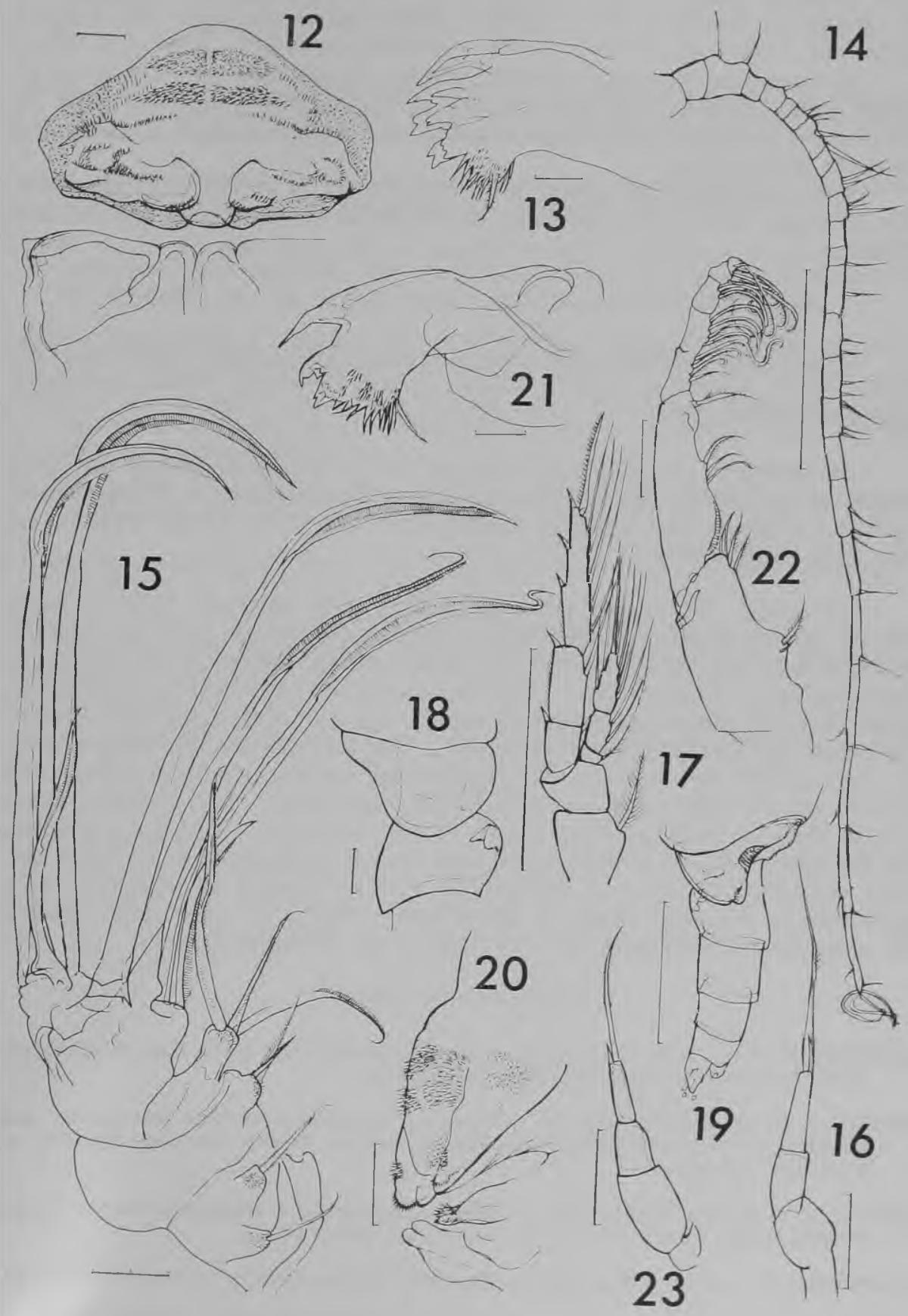


the mandible blade and the maxilliped of both species indicate a relationship between them. The fifth legs are very much like the fifth legs of $B$. longiseta Brodsky, the terminal spine being amongst the longest observed.

$B$. kanaevae, this new Atlantic species, is possibly the female of $B$. longicornis Tanaka. The new species is not identified with certainty as longicornis because of the completely different region in which it was found and the different sex.

The name kanaevae given to his species refers to Dr. Irina Kanaeva, the colleague who kindly gave me the material in which this species was found.

Bothypontia elongata Sars, 1905 (Figs. 10, 11, 18-23)

Synonymy: Bathypontia elongata Sars, 1905; Sars, 1924 pl. 126; Rose, 1933; Jespersen, 1940; Wilson, 1950; Vervoort, 1965; non Grice and Hülsemann, 1967.

Occurrence: at $31^{\circ} 10^{\prime}-31^{\circ} 14^{\prime} \mathrm{S}$ and $71^{\circ} 56^{\prime}-71^{\circ} 58^{\prime} \mathrm{W}$ during the third cruise of the USNS "Eltanin" to the Antarctic, caught by a Phleger corer between $3142 \mathrm{~m}$ and $1932 \mathrm{~m}$ depth, from 16.30 to 18.40 o'clock, on the 24th June 1962.

Remarks: Excepting some differences, this specimen agrees closely to the figures of $B$. elongata Sars (1924). It is larger than the Atlantic specimens, $6.15 \mathrm{~mm}$ in total length (prosome-mesosome $4.90 \mathrm{~mm}$ long, and urosome $145 \mathrm{~mm}$ long). The last mesosome segment is asymmetrical, with the left posterior border rounded and the right posterior border indented like in the Atlantic elongata. The rostrum is bifurcate, ending in two points and having two preterminal median small protuberances which are not registered in Sars' (1924) drawings. The terminal spine on the fifth leg is longer than in the Atlantic specimen. The hairy patches on the labrum are of a different pattern than that observed in $B$. kanaevae. The drawings in Grice \& Hülsemann (1967) labeled B. elongata refer probably to $B$. sarsi Grice \& Hülsemann (1965) or to a new species. $B$. elongata is mentioned, but not figured by Vervoort (1965).

\section{LITERATURE CITED}

BRODSKY, K. A. - 1950 - Calanoida of the Far Eastern and Polar Seas of the USSR. Tabl. Anal. Fauna USSR, 35: 1-442 (in Russian).

GRICE, G. D. \& HULSEMANN, K. - 1965 - Abundance, vertical distribution and taxonomy of calanoid copepods at selected stations in the northeast Atlantic. $J$. Zool., 146: 213-262.

GRICE, G. D. \& HUULSEMANN, K. - 1967 - Bathypelagic calanoid copepods of the western Indian Ocean. Proc. U.S. natn. Mus., 122: 1-67.

JESPERSEN, P. - 1940 - Non parasitic Copepoda. In: The Zoology of Iceland 3, 33:1-116. OWRE, H. B. \& FOYO, M. - 1967 - Copepods of the Florida Current. Fauna Caribbaea n.0 1: $137 \mathrm{pp}$. 
PARK, T. S. - 1970 - Calanoid Copepods from the Caribbean sea and Gulf of Mexico. 2 New Species and New Records from Plankton Samples. Bull. Mar. Sci., 20(2): 472-546.

ROSE, M. - 1933 - Copépodes pélagiques. Faune de France, 26: 1-374.

SARS, G. O. - 1905 - Liste préliminaire des Calanoidés recuellis pendant les campagnes de S.A.S. Ie Prince Albert de Monaco, avec diagnoses des genres et des espèces nouvelles (2e partie). Bull. Mus oceanogr. Monaco n.॰ 40: $24 \mathrm{pp}$.

SARS, G. O. - 1920 - Calanoidés recuellis pendant les campagnes de S.A.S. le Prince Albert de Monaco. (Nouveau supplément). Ibid. n.10 377: 20 pp.

SARS, G. O. - 1924 - Copépodes particulièrement bathypélagiques provenant des campagnes Scientifiques du Prince Albert ler de Monaco. Result. Camp. Sci. Monaco, 69, pls. 1-127.

SCOTT, A. - 1909 - The Copepoda of the Siboga Expedition: 1. Free-swimming, Littoral and Semi-parasitic Copepoda. Siboga Exped. Monogr., 29 a: 1-323.

TANAKA, O. - 1965 - The Pelagic Copepods of the Izu Region, Middle Japan. Systematic Account XIII: Parapontellidae, Acartiidae and Tortanidae. Publ. Seto Mar. Biol. Lab., 12(5): 379-408.

VERVOORT, W. - 1965 - Pelagic Copepoda Part II. Copepoda Calanoida of the families Phaennidae up to and including Acartidae. Atlantic Rep. n.o 8: 9-216.

WHEELER Jr., E. H. - 1970 - Atlantic Deep-Sea Calanoid Copepoda. Smithsonian Contr. Zool. n.o 55: $31 \mathrm{pp}$.

WILSON, C. B. - 1950 - Copepods gathered by the United States Fisheries Steamer "Albatross" from 1887 to 1909, chiefly in the Pacific Ocean. Bull. U.S. natn. Mus., 14(4) (= 100): I-IX, 141-441.

WOLFENDEN, R. N. - 1911 - Die Marinen Copepoden der Deutschen Südpolar Expedition und des Südlichen Eismeeres. Dtsch. Südpolar Exped., 12 (Zool. 4): 181-380. 
